\title{
Curriculum Development for Teaching Business Information Systems to Business Administration Students - An Example from a University of Applied Sciences
}

\author{
Roland Schwald \\ Department of Business and Computer Science, \\ Albstadt-Sigmaringen University
}

\section{Introduction}

The first universities of applied sciences (German: Fachhochschulen) were established between 1969 and 1971 in western Germany to offer students a university education, but - compared to scientific universities - with a clearer focus on the application of the major course concepts in the real world, be it enterprises, public institutions, non-governmental organizations or whatever. ${ }^{1}$

Though a lot has changed since then, including the oftentimes early adoption of bachelor and master degrees in recent years, universities of applied sciences still strife to offer their students a state-of-the-art professional education. In the case of business administration programs, a number of universities of applied sciences, including Albstadt-Sigmaringen University, the university referred to in this paper, have strengthened their curriculum by introducing and even extending business informatics courses offered.

In this paper I present a possible concept for the development of business informatics and here especially business software skills for a business administration program at a university of applied sciences in Germany. I will first describe the situation at Albstadt-Sigmaringen University in general and then proceed to explain the concept of teaching information systems to business administration students in detail. I will then mention some practical considerations before concluding with a very brief summary.

\footnotetext{
1 A comprehensive description of the concept of universities of applied sciences in Germany can be found in a 2003 publication from the Federal Ministry of Education and Research that is available at: http://www.bmbf.de/pub/universities_of_applied_sciences_in_germany.pdf, retrieved on 2009-1124.
} 


\section{Background}

The bachelor and master programs on which this example is based on are both full-time, general business administration programs. Experience shows that a considerable number of bachelor students and the majority of the master students at Albstadt-Sigmaringen University actually do have at least some work experience (including internships) and are to some extend already aware that today's enterprises extensively use and to a certain degree also depend on business information systems such as ERP systems. ${ }^{2}$ The fact that a number of business administration students are already to a certain degree sensitized regarding business information systems is certainly a positive aspect that shouldn't go unnoticed when developing course contents.

While in recent years it has become a matter of discussion internationally, also in the world of higher education of course, as to how far information technology (IT) itself really creates value and adds to the competitiveness of a business, ${ }^{3}$ the development of student-specific exercises and other relevant material in the area of business information systems has progressed and flourished. As an example for this one can mention the numerous excellent exercises and other documents provided by the SAP University Competence Centers (UCC) ${ }^{4}$ such as those in Munich and Magdeburg, Germany.

In the foreseeable future the development of even more content is likely and especially from the point of view of a smaller university of applied sciences needed in order to satisfy the education needs of tomorrows students.

For a traditional business administration program, it is important that one selects those IT subjects and exposes the students to those IT systems they probably will encounter later on in their early professional career as well. Therefore a clear concept is needed.

\section{Concept}

The basic concept of teaching business administration students the principals of corporate information systems rests on the following main qualifications and skills the students should have at the time he or she graduates from university:

- Obtaining in-depth working knowledge of information systems (e.g., how they work, how they are structured and so on).

\footnotetext{
2 ERP is an abbreviation for Enterprise Resource Planning. ERP systems provide a wide range of functions for processing standard business transactions. Well-known ERP system vendors include SAP AG, Oracle Corporation, The Sage Group plc., and Microsoft Corporation.

3 As an example one can mention the article "IT Doesn't Matter" by Nicholas G. Carr, Harvard Business Review, May 2003, p.41-49.

${ }^{4}$ SAP University Competence Centers provide support to universities who are members of the SAP Educational Alliance. They also host various SAP software systems that member universities can access.
} 
- Acquiring decision making skills (e.g., which system to choose based on requirements analysis).

- Gaining method competence (e.g., learning how to complete a sales transaction in SAP ERP).

- Learning social skills (e.g, working on a fictitious major ERP project as part of a project team).

To implement these requirements in the university's teaching it is important that the curriculum also emphasizes these skills. However, neither is it always possible nor does it always make sense to incorporating all four types of skills in one course. Therefore these skill types can be found to various degrees in the mandatory IT courses offered. In addition, it is important that the sequence of the mandatory IT courses is synchronized so that the courses can largely build upon each other.

A rough overlook of the sequence of the major contents of the mandatory IT courses offered is given in the following figure:

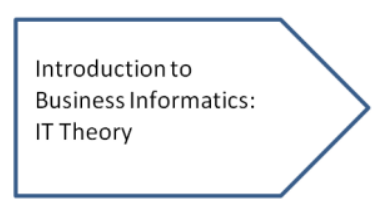

1. Semester (Bachelor)

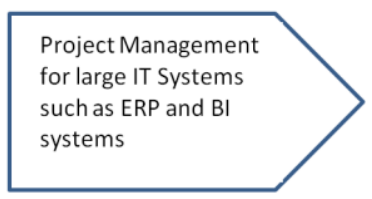

7. Semester (Bachelor)

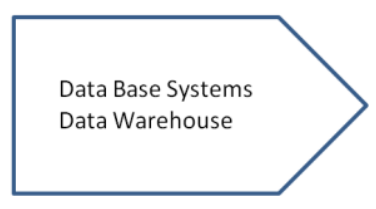

3. Semester (Bachelor)

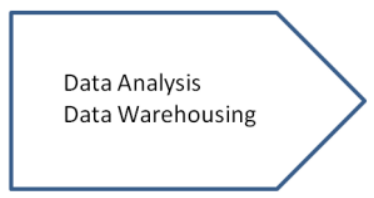

1. Semester (Master)

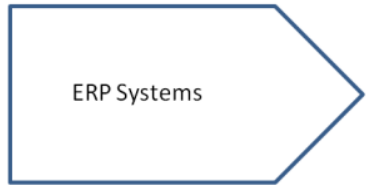

4. Semester (Bachelor)

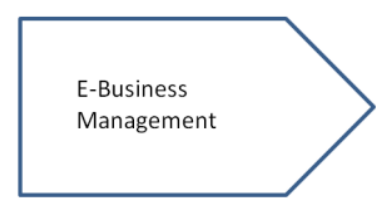

2. Semester (Master)

Figure 1: Sequence of IT content for business administration students

In the following chapter I will elaborate on the factual implementation of this concept.

\section{Implementation}

At many universities of applied sciences it is mandatory that students complete at least one internship semester. In our case, students are expected to go to a company or other relevant organization for their internship during their fifth semester of studies. The majority of the students will work with various information systems 
during their internship. It therefore makes a lot of sense to expose students to state-of-the-art business information systems before they complete their internship, i.e., at the latest in the fourth semester of their business administration studies.

Students at Albstadt-Sigmaringen University complete introduction and intermediate business informatics courses in their first and third semester of studies. In their forth semester they will be exposed to two large ERP systems: SAP ERP and Microsoft Dynamics (AX). SAP ERP was selected because of its market leader position at least among large enterprises in Europe. ${ }^{5}$ Microsoft Dynamics (AX) was selected for being a product more relevant for medium-sized companies. Many students select Albstadt-Sigmaringen University based on its good contacts to small- and especially medium-sized companies and also because a lot of the course contents of the business administration programs are especially relevant to that type of companies.

The in-class time for each of the ERP systems will be twelve teaching units. ${ }^{6}$ While this isn't exactly a huge amount of time, it is enough so that students grasp the general workings of both systems.

Since the students later on in their career will largely work alone on their IT systems without anybody sitting next to him or her, it is important that every student has the opportunity to work alone on one instance of the training system as well. However, since in our case the largest room with desktop PCs isn't large enough to accommodate all students, it was necessary to split the semester in different groups. For one group the room will be reserved in the morning, for the other in the afternoon. It is also essential that there are enough well-trained staff members available to help students if they encounter a problem for example. The SAP University Competence Centers offer regularly first-rate training courses that are also available to academic staff members of universities.

The students will first be introduced to the larger of the two systems: SAP ERP. The reason for this, amongst others, is to show the student from the beginning how complex business information systems really are and how important it is to understand how they work.

They will be given an overlook of the system and its functionality. After this they are assigned personal accounts that are valid for the rest of the semester, including the examination period at the end of the semester. The students sign on to SAP ERP with their new accounts and - with the help of handed out exercises they first learn how to navigate within the system. The idea is that before the students delve into technical and functional details of the system, they first should get

\footnotetext{
${ }^{5}$ N.U. (2008) SAP Holds Top Rankings in Worldwide Market Share for SAP® Business Suite Applications. Available at: http://www.sap.com/about/newsroom/press.epx?pressid=9913, retrieved on 2009-11-24. SAP AG notes on this page that its worldwide market share in the ERP sector was 27.5 percent in 2007. That data is based on a market share report by research company Gartner, according to SAP AG.

${ }^{6}$ One teaching unit is 45 minutes. Thus, 12 teaching units correspond to 9 clock hours.
} 
a "feel" for the system, how to enter data, ways to personalize the system, methods to find information in the system and so on.

In a second step, usually the week after the introduction seminary and the navigation exercises, the students will be given a handout with a complete case study. Alternating from semester to semester, the students will either complete a purchasing transaction from request to delivery and payment of the invoice or a sales transaction whereby the student's virtual company will sell a stock item. Here too the student will learn the complete cycle from initial order to its fulfillment.

After those twelve teaching units for the SAP part, the students will learn more about the ERP system Microsoft Dynamics (AX), formerly called "Axapta". It is one of several components of the Dynamics product range offered by Microsoft. The scheduled amount of teaching units for Microsoft Dynamics is also twelve.

The development of this course part will be similar to the one for the SAP ERP software, i.e., after an introduction to the system the students will have access to the system itself and will also complete a sales transaction case study, similar to the SAP exercise. As one result, the students then will be able to compare the two systems - at least based on said case study. They will be better able, e.g., to understand which system is more suitable for what type of company.

In a third step, the students will learn the concept of the event-driven process chains (EPCs) and how to model business processes with that method using the ARIS $^{7}$ software by IDS Scheer. Among other things, one of their assignments will be to model the workflow for the business process "sale of a stock item" as it is being carried out in SAP ERP and how that process is being handled in Microsoft Dynamics $(\mathrm{AX})$. By doing that the students can better see if and where there are differences between the two systems.

After the fourth semester, the students will have to complete an internship at a company or other organization. There, they will typically get in touch with various business information systems, such as ERP, SCM, CRM ${ }^{8}$ and similar information systems.

Anecdotal evidence leads to the conclusion that students can often apply concepts learned during classes at the university of applied science during their internship. Students make a good impression at the internship company by displaying relevant business information system skills. And in the end, this reflects well on the university as well. That in turn will make it easier for job applicants from that university to find employment later on. This is what is usually called a "win-win" situation.

\footnotetext{
7 ARIS stands for the German term Architektur integrierter Informationssysteme (English: Architecture of Integrated Information Systems). ARIS is an approach to enterprise modeling developed by Prof. August-Wilhelm Scheer.

8 SCM is the abbreviation for Supply Chain Management, CRM stands for Customer Relationship Management.
} 
During the seventh and last semester of the Bachelor of Science in Business Administration program the students will have to complete a comprehensive project on either business intelligence or enterprise resource planning. Those projects are based on specific - fictitious or real - cases where an organization plans to implement a new information system.

For that project to be successful, the students typically first have to establish a project plan and then have to define the requirements for the information systems. They will check the feasibility of the project and so on. In one of the next steps they will have to choose one of the information systems available and have to justify their decision in writing and during a project presentation.

Students will work on this project for the duration of the semester largely in groups. They will have to select a project manager among themselves who will be in charge of the project for the duration of the semester. This student project manager will be the contact person for the professors and other staff members from the university in charge of this course.

Those students who continue on to the Master of Science in Business and Management program - a consecutive Master of Science program - will get an even deeper insight into the value of large business information systems.

In the first semester of the Master of Science program, students will delve into the area of data warehouses. Using SAP BI ${ }^{9}$ and its Business Explorer, students will learn how a large data warehouse system handles reporting functions. The students will get their personal accounts for SAP BI in order to complete several reporting exercises.

They will learn to apply slicing, dicing, and pivoting amongst other OLAP 10 functions and see how these functions work in a large business intelligence system. To immerse themselves even further in the area of business intelligence, they will also get the chance to work with SPSS, an advanced statistics program. This program in this instance will be used to work on business analytics cases.

The following table 1 summarizes the major IT content that business administration students will complete during their studies.

\section{Practical Considerations}

The business administration programs at Albstadt-Sigmaringen University, on which this example is based on, offer a general business administration education and therefore have to take into account that the majority of the students attending the courses are not keen in learning IT content but are rather interested in business topics in general. Therefore, one consequence for example was that the students are required to take only a maximum of one IT related module per semester.

\footnotetext{
${ }^{9}$ Full name: SAP NetWeaver Business Intelligence. The main component of that system, a data warehouse, is called business warehouse.

${ }^{10}$ OLPA stands for Online Analytical Processing.
} 
Table 1: IT curriculum for Business Administration students

\begin{tabular}{|c|c|c|c|}
\hline & Semester & IT content & $\begin{array}{l}\text { IT tools I } \\
\text { systems used }\end{array}$ \\
\hline \multirow{7}{*}{ 品 } & 1st & Introduction to Business Information Systems & MS Excel \\
\hline & 2nd & --- & \\
\hline & 3 rd & $\begin{array}{l}\text { Intermediate Business Information Systems: } \\
\text { Database Management } \\
\text { Data Modeling } \\
\text { Data Warehouse }\end{array}$ & $\begin{array}{l}\text { Microsoft Approach } \\
\text { Microsoft Visio } \\
\text { SAP BI }\end{array}$ \\
\hline & 4th & $\begin{array}{l}\text { Advanced Business Information Systems: } \\
\text { ERP systems }\end{array}$ & $\begin{array}{l}\text { SAP ERP } \\
\text { MS Dynamics (AX) } \\
\text { ARIS Toolset }\end{array}$ \\
\hline & 5th & Internship & \\
\hline & 6th & Project: Standard Business Software & Microsoft Project \\
\hline & 7th & --- & \\
\hline \multirow{3}{*}{ 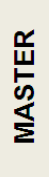 } & 1st & $\begin{array}{l}\text { Data Warehouse Systems } \\
\text { Data Analysis }\end{array}$ & $\begin{array}{l}\text { SAP BI } \\
\text { SPSS } \\
\text { Microsoft SQL Server }\end{array}$ \\
\hline & 2nd & E-Business Management & \\
\hline & $3 r d$ & --- & \\
\hline
\end{tabular}

Also, the course content and the specific IT systems used in those courses had to be highly relevant to business administration and management students.

The changeover from the old diploma program to the new bachelor program gave the university the chance to rethink the concept how it teaches IT to business administration students. The university profited from this changeover in that it was able to better synchronize the individual IT parts.

However, this changeover from the old system with only one program offered (the diploma program) to the new system with two programs (Bachelor and Master of Science) also posed problems. Despite being a so-called "consecutive" Master of Science program, a large part of the master students have not been students at the Bachelor of Science program at Albstadt-Sigmaringen University. The challenge therefore was to offer advanced business IT courses that would suit both, students who have completed the bachelor program at Albstadt-Sigmaringen University as well as those students who graduated from different universities and possibly have quite a different skill set when it comes to business information systems. It is important that the course content will appeal to both groups of students.

For example, the master students will get an introduction to SAP BI and they will also get to know another business intelligence system: Microsoft SQL Server. Thus the course will contribute to the learning of the university's former bachelor students as well as to master students who have earned their bachelor's degree at other universities. 
To build a sound concept for teaching information systems to business administration students it is important to find reliable partners in the IT industry that support such an approach. One of them is SAP AG, a company that with their support of the SAP University Competence Centers within the SAP University Alliance (UA) program substantially contributes to an up-to-date IT education.

Microsoft Corporation also supports universities by means of their Microsoft Dynamics Academic Alliance program. Member universities benefit for example in that they receive free online training and course materials.

\section{Conclusion}

This paper explained a possible curriculum for teaching information system content to business administration students at a university of applied sciences in Germany, based on an example from Albstadt-Sigmaringen University.

Starting point for the development of a curriculum are the relevant qualifications and skills the students should have at the time he or she graduates from university, such as method competences, working knowledge of relevant systems, social skills and decision-making skills. A practical approach to teaching business information systems is to accompany lectures with realistic exercises on major information systems.

Though this concept theoretically could be adopted by similar universities, one should point out that the curriculum design should certainly take into account the particularities of every individual institution. A mere takeover of concepts, including those presented in this paper, without adapting them to the realities of the relevant institution of higher education will probably not be crowned with success.

Further research should be carried out in order to assess the effectiveness of various curriculum concepts at relevant institutions in Europe.

\section{References}

Carr, Nicholas G. (2003) IT Doesn't Matter. Harvard Business Review, May 2003: 41-49.

N.U.: Module descriptions (in German) for the Bachelor of Science in Business Administration program at Albstadt-Sigmaringen University. Available at: http:/ /www.fhalbsig.de/ bwl/verweise/bachelor_module/modulbeschreibungen.htm, accessed on 2009-11-24. 
N.U.: Module descriptions (in German) for the Master of Science in Business Administration and Management program at Albstadt-Sigmaringen University. Available at: http://www.fhalbsig.de/ bwl/verweise/master_module/modulbeschreibungen.htm, accessed on 2009-11-24.

N.U. (2008) SAP Holds Top Rankings in Worldwide Market Share for SAP® Business Suite Applications. Available at: http://www.sap.com/about/newsroom/press.epx?pressid=9913, accessed on 2009-11-24.

N.U. (2003) Universities of Applied Sciences in Germany. Publisher: Federal Ministry of Education and Research (BMBF). Available at: http://www.bmbf.de/pub/universities_of_applied_sciences_in_germany.pdf, accessed on 2009-11-27. 